\title{
PENGARUH KADAR PROTEIN TERHADAP PERTUMBUHAN BENIH IKAN KERAPU LUMPUR, Epinephelus coioides
}

\author{
Ketut Suwirya, Muhammad Marzuqi, Nyoman Adiasmara Giri, Kaspriyo, dan Agus Prijono \\ ABSTRAK \\ Percobaan ini dilaksanakan untuk mengetahui kebutuhan protein pakan terhadap \\ pertumbuhan benih kerapu lumpur, Epinephelus coioides. Ikan percobaan dipelihara pada \\ kepadatan 10 ekor dalam bak ukuran $100 \mathrm{~L}$ dengan sistem air mengalir selama 9 minggu. Bobot \\ rata-rata benih kerapu lumpur setiap bak pada awal percobaan adalah 34,12 g. Pakan percobaan \\ dibuat dalam bentuk pelet kering dengan kandungan protein berbeda yaitu $36 \%, 42 \%, 48 \%, 54 \%$, \\ dan $60 \%$. Hasil percobaan menunjukkan bahwa kandungan protein dalam pakan mempengaruhi \\ pertumbuhan dan efisiensi pakan $(P<0,05)$. Kandungan protein pakan optimal untuk pertumbuhan \\ pada benih kerapu lumpur ukuran $34,12 \mathrm{~g}$ adalah $48 \%$.
}

ABSTRACT: Effect of dietary protein on growth of estuary grouper, Ephinephelus coioides juveniles. By: Ketut Suwirya, M. Marzuqi, Nyoman Adiasmara Giri, Kaspriyo, and Agus Prijono

\begin{abstract}
This experiment was conducted to know the requirement of dietary protein on growth of estuary grouper, Epinephelus coioides juvenile. Juveniles with average initial body weight of $34.12 \mathrm{~g}$ were reared in $100 \mathrm{~L}$ tank with flow through system for 9 weeks. The levels of protein in the test diets were $36 \%, 42 \%, 48 \%, 54 \%$, and $60 \%$. The result of the experiment showed that dietary protein affected growth and feed efficiency of estuary grouper $(P<0.05)$. The optimal level of protein in diet for growth of estuary grouper juvenile, $34.12 \mathrm{~g}$ in size, was $48 \%$.
\end{abstract}

KEYWORDS: estuary grouper, protein, feed, growth

\section{PENDAHULUAN}

Ikan kerapu merupakan komoditas perikanan bernilai ekonomis tinggi, terutama di pasar Asia seperti Hongkong, Singapore, dan China. Salah satu ikan kerapu yang banyak diminati pasar adalah kerapu lumpur (Epinephelus coioides). Didorong oleh permintaan pasar yang meningkat maka perlu diusahakan budi daya ikan kerapu tersebut. Saat ini usaha budi daya ikan kerapu berkembang di Kepulauan Riau, Lampung, Kepulauan Seribu, Kepulauan Karimunjawa, Sulawesi Selatan, dan Nusa Tenggara Barat.

Ikan kerapu lumpur mempunyai potensi yang cukup besar untuk dibudidayakan karena pertumbuhannya cepat, dapat menerima pakan dalam bentuk kering, dan mempunyai efisiensi pakan yang tinggi, dibandingkan dengan kerapu bebek. Sampai saat ini ikan rucah secara tradisional masih digunakan sebagai pakan kerapu pada keramba jaring apung. Kelemahan penggunaan ikan rucah adalah sangat mudah rusak, bergantung pada musim dan masih merupakan ikan konsumsi. Hal tersebut akan menyebabkan harga dan suplai ikan rucah sebagai pakan menjadi sulit diprediksi dan bila disimpan dalam jangka lama akan menurun kualitasnya. Oleh karena itu, pakan buatan perlu segera dikembangkan untuk mendukung pengembangan budi daya kerapu lumpur. Keunggulan pakan buatan adalah penanganannya lebih mudah, suplai dapat berlanjut, dan pakan dapat diformulasi sesuai dengan kebutuhan jenis ikan kerapu yang dibudidayakan.

Kerapu termasuk ikan karnivor yang umumnya memerlukan pakan dengan kandungan protein relatif tinggi. Kebutuhan protein dalam pakan untuk beberapa spesies kerapu dilaporkan berkisar antara $47,8 \%-60,0 \%$. Sampai saat ini belum tersedia informasi mengenai kebutuhan protein dan nutrien lainnya untuk benih kerapu lumpur. Padahal protein merupakan komponen biaya terbesar dalam pakan ikan.

Penelitian ini bertujuan untuk mengetahui kebutuhan protein pakan yang optimum untuk pertumbuhan benih ikan kerapu lumpur. Informasi ini sangat diperlukan sebagai dasar untuk pengembangan pakan ikan kerapu ini. 


\section{BAHAN DAN METODE}

Lima formulasi pakan percobaan dengan perlakuan kandungan protein yang berbeda yaitu $36 \%, 42 \%$, $48 \%, 54 \%$, dan $60 \%$ disajikan pada Tabel 1 . Semua pakan diformulasikan sehingga mempunyai kisaran energi $4,4-4,8 \mathrm{kkal} / \mathrm{g}$ pakan dengan menyesuaikan kandungan dekstrin. Pakan dibuat dalam bentuk pelet dengan diamater $3,6 \mathrm{~mm}$ dan dikeringkan menggunakan pengering beku (freeze dryer) kemudian disimpan pada freezer selama percobaan.

Sebagai wadah percobaan digunakan 15 buah bak polikarbonat volume $100 \mathrm{~L}$, dilengkapi dengan aerasi dan sistem air mengalir. Pada setiap bak dipelihara 10 ekor ikan kerapu lumpur dengan bobot awal 34,12 $\pm 12,11 \mathrm{~g}$ yang diperoleh dari alam. Rancangan percobaan adalah rancangan acak lengkap (RAL) dengan lima perlakuan dan setiap perlakuan mendapatkan tiga ulangan. Ikan diberi pakan secara perlahan sampai kenyang. Pemberian pakan dua kali per hari yaitu pukul 08.30 dan 15.00 . Pakan yang tidak dimakan dari masing-masing bak dikumpulkan untuk dikeringkan. Pengambilan sisa pakan dilakukan 1 jam setelah pemberian pakan. Untuk mengetahui perkembangan bobot ikan dilakukan penimbangan individu dari masing-masing bak setiap tujuh hari. Percobaan dilaksanakan selama 9 minggu. Pada akhir percobaan 3 ekor ikan dari masing-masing bak diambil, kemudian dibilas dengan air tawar dan dikeringkan dengan pengering beku (freeze dryer) untuk analisis proksimat seluruh tubuh.

Data hasil pengukuran bobot ikan digunakan untuk menghitung pertambahan bobot ikan dan efisiensi pakan. Analisis data pertambahan bobot, efisiensi pakan, dan komposisi tubuh pada akhir percobaan mempergunakan metode uji sidik ragam (Analysis of Variance-ANOVA) dilanjutkan dengan uji Beda Nyata Terkecil (Least Significant Difference-LSD) (Steel \& Torrie, 1980).

\section{HASIL DAN BAHASAN}

Kandungan protein pakan berpengaruh nyata terhadap pertumbuhan benih ikan kerapu lumpur

Tabel 1. Komposisi pakan percobaan

Table 1. Composition of experimental diets

\begin{tabular}{|c|c|c|c|c|c|}
\hline \multirow{2}{*}{$\begin{array}{c}\text { Bahan } \\
\text { Ingredients }\end{array}$} & \multicolumn{5}{|c|}{ Protein pakan (Dietary protein) } \\
\hline & $36 \%$ & $42 \%$ & $48 \%$ & $54 \%$ & $60 \%$ \\
\hline Kasein (Casein) & 12.00 & 14.00 & 16.00 & 18.00 & 20.00 \\
\hline Tepung ikan (Fish meal) & 24.00 & 28.00 & 32.00 & 36.00 & 40.00 \\
\hline Tepung hati cumi (Squid liver meal) & 6.00 & 7.00 & 8.00 & 9.00 & 10.00 \\
\hline Tepung rebon (Tiny shrimp meal) & 7.75 & 8.75 & 10.00 & 11.25 & 12.50 \\
\hline Min. $\operatorname{mix}^{1}$ & 2.50 & 2.50 & 2.50 & 2.50 & 2.50 \\
\hline Vit. $\mathrm{Mix}^{2}$ & 2.00 & 2.00 & 2.00 & 2.00 & 2.00 \\
\hline Minyak ikan (Fish oil) & 5.59 & 5.09 & 4.59 & 4.09 & 3.59 \\
\hline Lesitin (Lecithin) & 1.31 & 1.31 & 1.31 & 1.31 & 1.31 \\
\hline Dekstrin (Dextrin) & 30.98 & 22.12 & 15.28 & 7.42 & 0.00 \\
\hline Terigu (Wheatflour) & 3.00 & 3.00 & 3.00 & 3.00 & 3.00 \\
\hline $\mathrm{CMC}$ & 3.00 & 3.00 & 3.00 & 3.00 & 3.00 \\
\hline Asthaxanthin & 0.10 & 0.10 & 0.10 & 0.10 & 0.10 \\
\hline Selulos (Celluloce) & 1.77 & 3.13 & 2.22 & 2.33 & 2.00 \\
\hline Total & 100.00 & 100.00 & 100.00 & 100.00 & 100.00 \\
\hline \multicolumn{6}{|c|}{ Analisis proksimat (Proximate analysis) } \\
\hline Protein $(\%)$ & 36.21 & 42.85 & 48.05 & 54.90 & 60.01 \\
\hline Lemak (Lipid) $(\%)$ & 9.01 & 10.10 & 10.45 & 11.01 & 11.25 \\
\hline Serat (Fibre) (\%) & 4.01 & 5.90 & 3.80 & 3.50 & 3.10 \\
\hline Abu (Ash) (\%) & 8.12 & 8.90 & 8.80 & 10.10 & 10.71 \\
\hline BETN (Extact-free $N)(\%)$ & 42.65 & 32.25 & 28.90 & 20.49 & 14.93 \\
\hline
\end{tabular}

Mineral mix ( $\mathrm{mg} / 100 \mathrm{~g}$ pakan (feed)): $\mathrm{KH}_{2} \mathrm{PO}_{4} 412, \mathrm{CaCO}_{3} 282, \mathrm{Ca}\left(\mathrm{H}_{2} \mathrm{PO}_{4}\right) 618, \mathrm{FeCl}_{3} 4 \mathrm{H}_{2} \mathrm{O}$ 166, $\mathrm{ZnSO} 49.99$, $\mathrm{MnSO}_{4} 6.3, \mathrm{CuSO}_{4} 2, \mathrm{CoSO}_{4} .7 \mathrm{H}_{2} \mathrm{O} 0.05, \mathrm{KJ} 0.15$, Dextrine 450, Cellulose 553.51

2 Vitamin mix ( $\mathrm{mg} / 100 \mathrm{~g}$ pakan) (Vitamin mix: $\mathrm{mg} / 100 \mathrm{~g}$ diet): thiamin-HCl 5.0; riboflavin 5.0; Ca-pantothenate 10.0; niacin2.0; pyridoxine-HCl 4.0; biotin 0.6; folic acid 1.5; cyanocobalamin 0.01; inositol 200.0; $p$ aminobenzoic acid 5.0; menadion 4.0; b-caroten 15.0; calciferol 1.9; a-tocoferol 20.0; cholin chloride 900.0 
$(P<0,05)$. Tabel 2 menunjukkan bahwa benih ikan kerapu lumpur yang diberi pakan dengan kadar protein $36 \%$ dan $42 \%$ memberikan pertumbuhan bobot yang lebih rendah dibandingkan dengan pakan yang proteinnya 48 hingga $60 \%$, sedangkan pakan dengan kadar protein $48 \%, 54 \%$, dan $60 \%$ memberikan pertumbuhan bobot yang tidak berbeda nyata $(P>0,05)$. Hal ini menunjukkan bahwa pakan dengan kadar protein $48 \%$ adalah optimum untuk pertumbuhan bobot benih ikan kerapu lumpur.

Benih beberapa jenis spesies kerapu dari jenis Epinephelus juga dilaporkan membutuhkan pakan dengan kandungan protein yang relatif tinggi untuk dapat tumbuh dengan baik. Kebutuhan protein benih kerapu Epinephelus areolatus dilaporkan mencapai $60 \%$ (Chu et al., 1995; Chen et al., 1995), Epinephelus salmoides $50 \%$ (Teng et al., 1978), Epinephelus malabaricus 47,8\%-50,2\% (Chen \& Tsai, 1994; Shiau \& Lan, 1996), dan Epinephelus striatus kebutuhan proteinnya di atas $55 \%$ (Ellis et al., 1996). Kebutuhan protein yang optimum benih kerapu bebek (Cromileptes altivelis) adalah 52,4\% (Giri et al., 1999). Lebih lanjut Ellis et al. (1996) melaporkan bahwa pakan dengan kandungan protein di atas $55 \%$ dan energi/ protein rasio di bawah $28,9 \mathrm{kj} / \mathrm{gram}$ menghasilkan pertumbuhan benih ikan kerapu Epinephelus salmoides yang optimum.

Tabel 2 menunjukkan bahwa peningkatan kadar protein pakan akan meningkatkan efisiensi pakan pada kerapu lumpur $(P<0,05)$. Hal ini dapat dilihat bahwa kerapu lumpur yang diberi pakan dengan kandungan protein $36 \%$ sampai $42 \%$ mempunyai efisiensi pakan yang lebih rendah dibandingkan dengan ikan yang diberi pakan dengan kandungan protein $54 \%$ sampai $60 \%$.

Ikan yang diberi pakan dengan kandungan protein $48 \%, 54 \%$, dan $60 \%$ mempunyai efisiensi pakan yang tidak berbeda nyata ( $P>0,05)$, namun ikan yang diberi pakan dengan kandungan protein $48 \%$ mempunyaj efisiensi pakan yang lebih rendah dibandingkan dengan pakan yang mengandung protein $60 \%$ $(P<0,05)$. Meningkatnya efisiensi pakan dengan meningkatnya kandungan protein pakan juga telah ditemukan pada ikan Sparus aurata (Luquet \& Sabaut, 1973; Vergara et al., 1996) dan Cromileptes altivelis (Giri et al., 1999). Hal ini menunjukkan adanya kemungkinan bahwa ikan-ikan laut lebih mudah memanfaatkan energi dari protein dari pada sumber energi lainnya. Oleh karena itu, perlu dilakukan penelitian lebih lanjut untuk mengetahui rasio proteinenergi dan sumber energi yang mudah dimanfaatkan penggunaan protein seefisien mungkin.

Peningkatan kandungan protein pakan di atas tingkat optimum dapat menurunkan laju pertumbuhan dan efisiensi pakan sebagaimana dilaporkan oleh Vergara et al. (1996) untuk benih ikan Sparus aurata. Kebutuhan protein ikan Sparus aurata mencapai $55 \%$ dengan laju pertumbuhan spesifik 2,4\% per hari. Peningkatan kandungan protein pakan menjadi $60 \%$ dan $65 \%$ menghasilkan laju pertumbuhan spesifik yang lebih rendah yaitu berturut-turut $2,23 \%$ dan $1,74 \%$ per hari. Fenomena ini dapat dijelaskan bahwa tidak tersedia cukup energi untuk deaminasi dan ekskresi kelebihan asam amino yang diabsorbsi dari pemecahan protein yang terlalu tinggi (Chen \& Tsai, 1994). Pada penelitian kerapu lumpur (Tabel 2) menunjukkan bahwa peningkatan kandungan protein pakan dari $48 \%$ menjadi $60 \%$ tidak menunjukkan pengaruh yang nyata terhadap pertumbuhan $(P<0,05)$. Hal ini menunjukkan bahwa kerapu lumpur masih toleran terhadap kelebihan protein dengan mengkonversi protein pakan yang tinggi menjadi penggunaan pakan menjadi lebih efisien (Tabel 2).

Kandungan protein pakan juga berpengaruh nyata terhadap kadar air, protein kasar, dan lemak tubuh ikan setelah percobaan (Tabel 3). Ikan yang diberi

Tabel 2. Pertambahan bobot (\%) dan efisiensi pakan ikan kerapu lumpur yang diberi pakan dengan pakan percobaan

Table 2. Weight gain (\%) and feed efficiency of estuary grouper fed with experimental diets

\begin{tabular}{ccc}
\hline $\begin{array}{c}\text { Kadar prote in pakan } \\
\text { Dietary protein (\%) }\end{array}$ & $\begin{array}{c}\text { Pertambahan bobot } \\
\text { Weight gain (\%) }\end{array}$ & $\begin{array}{c}\text { Efisiensi pakan } \\
\text { Feed efficiency }\end{array}$ \\
\hline 36 & $74.22 \pm 2.06^{\mathrm{a}}$ & $0.51 \pm 0.08^{\mathrm{a}}$ \\
42 & $74.12 \pm 1.71^{\mathrm{a}}$ & $0.53 \pm 0.04^{\mathrm{a}}$ \\
48 & $80.30 \pm 4.58^{\mathrm{b}}$ & $0.60 \pm 0.03^{\mathrm{ba}}$ \\
54 & $89.38 \pm 3.02^{\mathrm{b}}$ & $0.64 \pm 0.03^{\mathrm{bc}}$ \\
60 & $84.64 \pm 3.27^{\mathrm{b}}$ & $0.73 \pm 0.09^{\mathrm{c}}$ \\
\hline
\end{tabular}

- Nilai dalam kolom yang diikuti oleh huruf yang sama tidak berbeda nyata $(P<0,05)$ Value in column followed by the same superscript are not significantly different $(P<0.05)$ 
Tabel 3. Komposisi tubuh ikan kerapu lumpur pada akhir percobaan

Table 3. Body composition of estuary grouper at the end of experiment

\begin{tabular}{ccccc}
\hline $\begin{array}{c}\text { Protein pakan } \\
\text { Dietary protein } \\
(\%)\end{array}$ & $\begin{array}{c}\text { Kadar air } \\
\text { Moisture (\%) }\end{array}$ & $\begin{array}{c}\text { Protein dim. bobot } \\
\text { Protein in dry matter } \\
(\%)\end{array}$ & $\begin{array}{c}\text { Lemak dim. bobot } \\
\text { Lipid in dry matter (\%) }\end{array}$ & $\begin{array}{c}\text { Abu dlm bobot } \\
\text { Ash in dry matter } \\
(\%)\end{array}$ \\
\hline 36 & $72.0 \pm 1.4^{\mathrm{b}}$ & $55.7 \pm 1.5^{\mathrm{a}}$ & $17.1 \pm 0.9^{\mathrm{a}}$ & $17.6 \pm 1.0^{\mathrm{a}}$ \\
42 & $70.0 \pm 0.8^{\mathrm{ab}}$ & $57.8 \pm 0.5^{\mathrm{ab}}$ & $19.2 \pm 0.6^{\mathrm{ab}}$ & $18.1 \pm 0.9^{\mathrm{a}}$ \\
48 & $69.2 \pm 0.9^{\mathrm{a}}$ & $60.0 \pm 1.2^{\mathrm{bc}}$ & $20.5 \pm 0.9^{\mathrm{b}}$ & $17.9 \pm 1.0^{\mathrm{a}}$ \\
54 & $68.1 \pm 0.5^{\mathrm{a}}$ & $62.1 \pm 1.3^{\mathrm{c}}$ & $21.3 \pm 0.6^{\mathrm{b}}$ & $19.0 \pm 1.8^{\mathrm{a}}$ \\
60 & $68.9 \pm 0.8^{\mathrm{a}}$ & $61.2 \pm 1.5^{\mathrm{bc}}$ & $20.9 \pm 0.7^{\mathrm{b}}$ & $18.9 \pm 2.0^{\mathrm{a}}$ \\
\hline
\end{tabular}

* $\quad$ Nilai dalam kolom yang diikuti oleh huruf yang sama tidak berbeda nyata $(P<0,05)$

Value in column followed by the same superscript are not significantly different $(P<0.05)$

pakan dengan kandungan protein 36\% mengandung kadar air nyata lebih tinggi dibandingkan dengan ikan yang diberi pakan dengan kandungan protein $48 \%$ sampai $60 \%(P<0,05)$. Perubahan kadar air tubuh benih ikan kerapu lumpur berlawanan arah dengan perubahan kadar lemak tubuh (Tabel 3), hal tersebut sesuai dengan yang disampaikan Lagler et al. (1977) dan Sherer (1994). Fenomena ini sebagai indikasi bahwa kelebihan energi dari protein disimpan dalam tubuh dalam bentuk lemak.

Kandungan protein dan lemak ikan meningkat dengan meningkatnya kandungan protein pakan. Ikan yang diberi pakan dengan kandungan protein $48 \%$, $54 \%$, dan $60 \%$ diperoleh kandungan protein dalam tubuh ikan tidak berbeda nyata $(P>0,05)$ namun nyata lebih tinggi dibandingkan dengan ikan yang diberi pakan dengan kandungan $36 \%(P<0,05)$. Kandungan protein tubuh benih kerapu lumpur relatif stabil diberi pakan dengan kandungan protein pakan $48 \%, 54 \%$, dan $60 \%$. Pola tersebut sebagai indikasi bahwa kapasitas sintesis protein dalam tubuh sudah mencapai maksimum atau kekurangan energi dalam sintesis protein seperti yang disampaikan oleh Pfeffer (1982) pada ikan salmon.

Secara kuantitatif terlihat bahwa kebutuhan protein benih ikan kerapu lumpur ini relatif lebih rendah dari beberapa benih jenis kerapu lain seperti Epinephelus areolatus, Epinephelus salmoides, dan kerapu bebek (Cromileptes altivelis). Kebutuhan protein yang relatif tinggi ini dapat merupakan kendala dalam pemilihan bahan baku untuk memenuhi formulasi pakannya. Umumnya sumber protein pakan ikan diperoleh dari tepung ikan yang mahal sehingga harga pakan akan menjadi sangat mahal pula. Untuk itu telah banyak dicari jalan untuk mengurangi tepung ikan. Salah satu alternatif adalah protein nabati, seperti tepung kedelai atau biji-bijian lainnya. Hasil percobaan pada benih kerapu bebek menunjukkan bahwa sumber protein pakan yang berasal dari tepung ikan dapat disubstitusi dengan sumber protein yang berasal dari bungkil kedelai sebanyak $10 \%$ (Marzuqi et al., 2004). Namun usaha ini tidak selalu sukses mengingat kemampuan ikan dalam memanfaatkan protein nabati juga terbatas. Alternatif lain dengan menekan kebutuhan protein dapat dengan cara mengoptimalkan antara kandungan protein dan kandungan energi dalam pakan. Hal ini telah dilakukan oleh Shiau \& Lan (1996) di mana kandungan protein pakan Epinephelus malabaricus dapat diturunkan dari 50,2\% menjadi $44 \%$ dengan mempertahankan kandungan energi $340-375 \mathrm{kkal} / 100 \mathrm{~g}$ pakan.

\section{KESIMPULAN}

Kandungan protein pakan yang optimum untuk pertumbuhan benih ikan kerapu lumpur, Epinephalus coioides adalah $48 \%$.

\section{DAFTAR PUSTAKA}

Chen, H.Y. and J.C. Tsai. 1994. Optimal dietary protein level for the growth of juvenil grouper Epinephalus malabaricus, fed semifurified diets. Aquaculture, 119: 265-271

Chen, X., L. Lin, and H. Hong. 1995. Optimum content of protein in artificial diet for Epinephalus akaara. J. Oceanogr., 14: 407-412.

Chu, J.L.W., KMY. Leung, and RSS Wu. 1995. Nutritional study on the areolated grouper (Epinephalus areolatus) culture in open sea cages. Proc. the Pecon Conference on Sustainable Aquaculture, 11-14 June 1995. Honolulu, $79 \mathrm{pp}$

Ellis, S., G. Viala, and W.O. Watanabe. 1996. Growth and feed utilization of hatchery reared juveniles nassau grouper fed four practical diets. Prog. Fish. Cult., 58: 167-172.

Giri, N.A., K. Suwirya, dan M. Marzuqi. 1999. Kebutuhan protein, lemak, dan vitamin $C$ untuk yuwana ikan kerapu bebek (Cromileptes altivelis). J. Pen. Per. Indonesia, 5(3): 38-46. 
Luquet, P. and J.J. Sabaut. 1973. Preliminary study on protein requirement of gilthead sea bream, Sparus aurata. Stud. Rev./Gen. Fish. Counc. Med., 52: 8290.

Lagler, K.F., J.E. Bardach., R.R. Miller, and D.R.M. Passino. 1977. Ichtiology. $2^{\text {od }}$ ed., John Wiley and Sons, New York, p. 153-163.

Marzuqi, M., N.A. Giri, and K. Suwirya. 2004. Effect of soybean meal as a substitution of fish meal in diet on growth of humpback grouper (Cromileptes altivelis). Indonesian Fish. Res. J., X(1): 39--42

Pfeffer, E. 1982. Utilization of dietary protein by salmonid fish. Comp. Biochem. Physiol.,73B, p. 51-57.

Sherer, K.D. 1994. Factor affecting the proximate composition of cultured fished with emphasis on salmonids. Aquaculture, 119: $63-88$.
Shiu, S.Y. and C.W. Lan. 1996. Optimum dietary protein level nd protein to energy ratio for growth of grouper (Epinephelus malabaricus). Aquaculture, 145:259266.

Steel, R.G.D. and J.H. Torrie. 1980. Principles and Procedures of statistics. McGrow Hill, New York, U.S.A. $633 \mathrm{pp}$.

Teng, S.K., T.E. Chua, and P.E. Lim. 1978. Preliminary observation on the dietary protein requirement of estuary grouper, Epinephelus salmoides Maxwell, cultured in floating net-cages. Aquaculture, 15: 257271

Vergara, J.M., L. Rpbianan, M. Izquierdo, and M.D.L. Hiquera. 1996. Protein sparing effect of lipid in the diets for fingerling of gilthead sea bream. Fish. Sci., 62(4): $624-628$ 
